\title{
A prospective randomized double blind Study of the effects of caudal clonidine and dexmedetomidine as an adjunct to caudal bupivacaine for postoperative analgesia in paediatric patients undergoing subumblical surgery.
}

\author{
Ishrat Rashid ${ }^{1}$, Khairat Mohammad ${ }^{2}$, Mohamad Ommid ${ }^{3}$, Mubasher Ahmad ${ }^{4}$, \\ Sheikh Irshad ${ }^{5}$,Velayat $\mathrm{Nabi}^{6}$ \\ 1, 2, 5.6 (Anesthesiology and critical care, Sher-i-Kashmir institute of Medical Science Srinagar, India) \\ 3, 4 (Lecturer Anaesthesiology and critical care, Government medical college Srinagar, India)
}

\begin{abstract}
In this study, we compared the analgesic efficacy and safety of caudal dexmedetomidine and clonidine added to caudal bupivacaine for postoperative analgesia in children undergoing subumblical surgeries. 90 patients aged 1 to 8 years scheduled for subumblical surgeries were randomly allocated into three groups of 30 patients each. Group A received $1 \mathrm{ml} / \mathrm{kg}$ of $0.25 \%$ bupivacaine with dexmedetomidine $2 \mu \mathrm{g} / \mathrm{Kg}$ in normal saline $1 \mathrm{ml}$. Group B received $1 \mathrm{ml} / \mathrm{kg}$ of $0.25 \%$ bupivacaine with clonidine $2 \mu \mathrm{g} / \mathrm{Kg}$ in normal saline $1 \mathrm{ml}$ and Group C received $1 \mathrm{ml} / \mathrm{kg}$ of $0.25 \%$ bupivacaine with normal saline $1 \mathrm{ml}$. All the patients in our study remained hemodynamically stable throughout the intraoperative and postoperative period. Addition of either dexmedetomidine $2 \mu \mathrm{g} / \mathrm{kg}$ or clonidine $2 \mu \mathrm{g} / \mathrm{kg}$ to $0.25 \%$ caudal bupivacaine significantly prolonged the postoperative analgesia time without increasing the incidence of side effects like nausea, vomiting, pruritis or urinary retention. Moreover dexmedetomidine did not offer significant advantage over clonidine as regards the duration of postoperative analgesia.
\end{abstract}

Keywords: bupivacaine, caudal, clonidine and dexmedetomidine

\section{Introduction}

Pain after surgery is inevitable. Relieving pain is one of the fundamental responsibilities of anesthesiologist. The density of nociceptive nerve endings in the skin of newborn infants is similar to or greater than that in adults. The provision of adequate analgesia is necessary after any surgery and it is all more important in children ${ }^{[1]}$. Caudal block has become the most popular regional anaesthetic technique for use in children. It provides excellent analgesia during surgery as well as during postoperative period in subumblical surgeries in children ${ }^{[2]}$. A number of non-opioid additives have been suggested to increase the quality and duration of analgesia by local anesthetics. The various non opioid additives include ketamine, midazolam, neostigmine, clonidine and more recently dexmedetomidine ${ }^{[3,4]}$. Alpha 2 adrenergic receptor agonists like clonidine and dexmedetomidine have relevant physiological properties causing sedation and analgesia, reducing plasma catecholamine levels, attenuating the stress response to surgery and preventing shivering through alpha 2 adrenoreceptors in central nervous system ${ }^{[5]}$. Dexmedetomidine is a highly selective $\square 2$ adrenergic agonist. It has a $\square 2 / \square 1$ selectivity ratio of 1600:1 compared with clonidine which has $\square 2 / \square 1$ selectivity ratio of 200:1, making it a complete $\square 2$ receptor agonist ${ }^{[6]}$. The mechanism of action of dexmedetomidine is unique and differs from those of currently used sedatives ${ }^{[7]}$.

The present study was undertaken to the analgesic efficacy and safety of caudal dexmedetomidine and clonidine added to caudal bupivacaine for postoperative analgesia in children undergoing subumblical surgeries.

\section{Material and Methods}

After obtaining approval from ethical committee of the institute and informed parental consent, 90 patients of physical status ASA I and II of either sex, aged 1 to 8 years scheduled for subumblical surgeries were prospectively enrolled in this study. During the preoperative visit, all patients were evaluated and assessed. No premeditation was given to any patient. In the operation theatre after connecting the patient to the monitors, an intravenous line was established. General anaesthesia was induced with standard doses of thiopental (4 to $6 \mathrm{mg} / \mathrm{kg})+$ Atracurium $(0.5 \mathrm{mg} / \mathrm{kg})$ to facilitate intubation and maintained with $0.5 \%$ to $1 \%$ of halothane and $66 \%$ Nitrous oxide in combination with $33 \%$ of oxygen, administered via laryngeal mask airway (LMA) or endotracheal tube. Muscle relaxation was achieved by the use of top up doses of atracurium. No intravenous or per rectal analgesic drugs were given to any patient intra operatively. Patients were randomly allocated into three groups of 30 patients each. 
Group A received $1 \mathrm{ml} / \mathrm{kg}$ of $0.25 \%$ bupivacaine with dexmedetomidine $2 \mu \mathrm{g} / \mathrm{Kg}$ in normal saline $1 \mathrm{ml}$.

Group B received $1 \mathrm{ml} / \mathrm{kg}$ of $0.25 \%$ bupivacaine with clonidine $2 \mu \mathrm{g} / \mathrm{Kg}$ in normal saline $1 \mathrm{ml}$

Group $\mathrm{C}$ received $1 \mathrm{ml} / \mathrm{kg}$ of $0.25 \%$ bupivacaine with normal saline $1 \mathrm{ml}$.

The study drugs were prepared by an anesthesiologist who was not involved in the study. All study drugs were kept at room temperature and used within 30 minutes of preparation.

After induction of anaesthesia, patients were placed in lateral decubitus position. A short beveled 23 Gauge hypodermic needle was introduced in caudal epidural space under full aseptic precautions; single dose caudal block was performed. Skin incision was allowed after 15 minutes of caudal block. The aim was to record the blood pressure and heart rate just before and after surgical incision and then every five minutes till the end of surgery. An increase in systolic blood pressure and heart rate $>15 \%$ of preincisional values was considered as failed block and rescue analgesia in the form of fentanyl $1-5 \square \mathrm{g} / \mathrm{kg}$ bodyweight intravenously was administered and these cases were eliminated from the study. At the end of surgery, residual neuromuscular blockade was reversed with appropriate doses of neostigmine and atropine and patients were transferred to postoperative care unit (PACU). In the PACU, patients were monitored for one hour and following parameters were recorded at 30 minute interval: Heart rate, Systolic non-invasive blood pressure, Oxygen saturation $\left(\mathrm{SpO}_{2} \%\right)$. Patients were also assessed for pain at 30 minute interval upto one hour in PACU by using FLACC pain scale scoring.

\section{The FLACC Pain Scale}

\begin{tabular}{|l|l|l|l|}
\hline Categories & \multicolumn{1}{|c|}{ 0 } & \multicolumn{1}{|c|}{ Scoring } \\
\hline Face & $\begin{array}{l}\text { Smile or no particular } \\
\text { expression }\end{array}$ & $\begin{array}{l}\text { Occasional grimace or frown, } \\
\text { withdrawn, disinterested }\end{array}$ & $\begin{array}{l}\text { Frequent to constant frown, } \\
\text { clenched jaw, quivering chin }\end{array}$ \\
\hline Legs & Normal position or relaxed & Uneasy, restless, tense & Kicking, or legs drawn up \\
\hline Activity & $\begin{array}{l}\text { Lying quietly, normal position, } \\
\text { moves easily }\end{array}$ & $\begin{array}{l}\text { Squirming, shifting back and } \\
\text { forth, tense }\end{array}$ & Arched, rigid, or jerking \\
\hline Cry & No cry (awake or asleep) & $\begin{array}{l}\text { Moans or whimpers occasional } \\
\text { complaint }\end{array}$ & $\begin{array}{l}\text { Crying steadily, screams or sobs, } \\
\text { frequent complaints }\end{array}$ \\
\hline Consol ability & Content, relaxed & $\begin{array}{l}\text { Reassured by occasional } \\
\text { touching, hugging or talking to, } \\
\text { distractible }\end{array}$ & Difficult to console \\
\hline
\end{tabular}

This scale is used for assessment of pain in children. There are five parameters in this scale, each given a score of $0-2$. Total score was taken to assess the pain.

\begin{tabular}{|c|c|}
\hline Severity of pain & Pain Score \\
\hline No pain & 0 \\
\hline Mild pain & $1-3$ \\
\hline Moderate pain & $4-7$ \\
\hline Severe pain & $8-10$ \\
\hline
\end{tabular}

After discharge from PACU, patients were again assessed for pain at 2 hours, 4 hours and at 6 hours and then every four hourly for 18 hours and then at 24 hours of postoperative period by ward nurse who was unaware of the caudal treatment received by the patients. The time from arrival in PACU to first time the FLACC score was $\geq 4$, was recorded and noted as the duration of adequate caudal analgesia. Rescue analgesia was given in the form of rectal paracetamol $(20 \mathrm{mg} / \mathrm{kg} / \mathrm{dose})$ if pain score was $\geq 4$. The number of doses of rescue medication required and the time of first administration of rescue medication was also noted in all the three groups.

After completion of study the data was analyzed using SPSS version 17.0 computer software. Numerical variables were presented as mean and standard deviation (SD) and categorical variables were presented as percentages. One - way ANOVA was used for between - group comparisons of numerical variables. Chi square test was used for between - group comparisons of categorical variables. Student's ' $t$ ' test was also used for analysis of difference of means for quantitative data. The tests were referenced for $\mathrm{p}$ values for their significance. Any P-value less than $0.05(\mathrm{p}<0.05)$ was taken as statistically significant. 


\section{Results}

90 patients were recruited in the study. All the groups were comparable with respect to age, body weight and duration of surgery. The three groups were comparable with regard to baseline hemodynamic variables. (TABLE 1)

Table - 1: Demographic data and baseline Hemodynamic parameters

\begin{tabular}{|c|c|c|c|c|}
\hline Parameter & $\begin{array}{c}\text { Group A Mean } \pm \\
\text { SD }\end{array}$ & $\begin{array}{c}\text { Group B } \\
\text { Mean } \pm \text { SD }\end{array}$ & $\begin{array}{c}\text { Group C } \\
\text { Mean } \pm \text { SD }\end{array}$ & P value \\
\hline Age (years) & $5.0 \pm 2.14$ & $4.3 \pm 2.16$ & $3.7 \pm 2.5$ & $0.082(\mathrm{NS})$ \\
\hline Weight (kgs) & $17.76 \pm 3.98$ & $17.73 \pm 5.66$ & $15.17 \pm 6.5$ & $0.102(\mathrm{NS})$ \\
\hline $\begin{array}{c}\text { Duration of Surgery } \\
\text { (min) }\end{array}$ & $39.0 \pm 7.6$ & $38.0 \pm 7.8$ & $39.0 \pm 9.43$ & $0.58(\mathrm{NS})$ \\
\hline Heart Rate (beats/min.) & $117.23 \pm 10.12$ & $114.66 \pm 10.7$ & $113.33 \pm 12.27$ & $0.421(\mathrm{NS})$ \\
\hline $\begin{array}{c}\text { Systolic Blood Pressure } \\
(\mathrm{mmHg})\end{array}$ & $104.43 \pm 10.74$ & $102.66 \pm 10.36$ & $105.03 \pm 9.55$ & $0.561(\mathrm{NS})$ \\
\hline
\end{tabular}

In the study, hemodynamic effects with regards to heart rate and systolic blood pressure showed a benign profile and no clinically relevant change was observed in these variables at various study stages. (Figure I and Figure II)
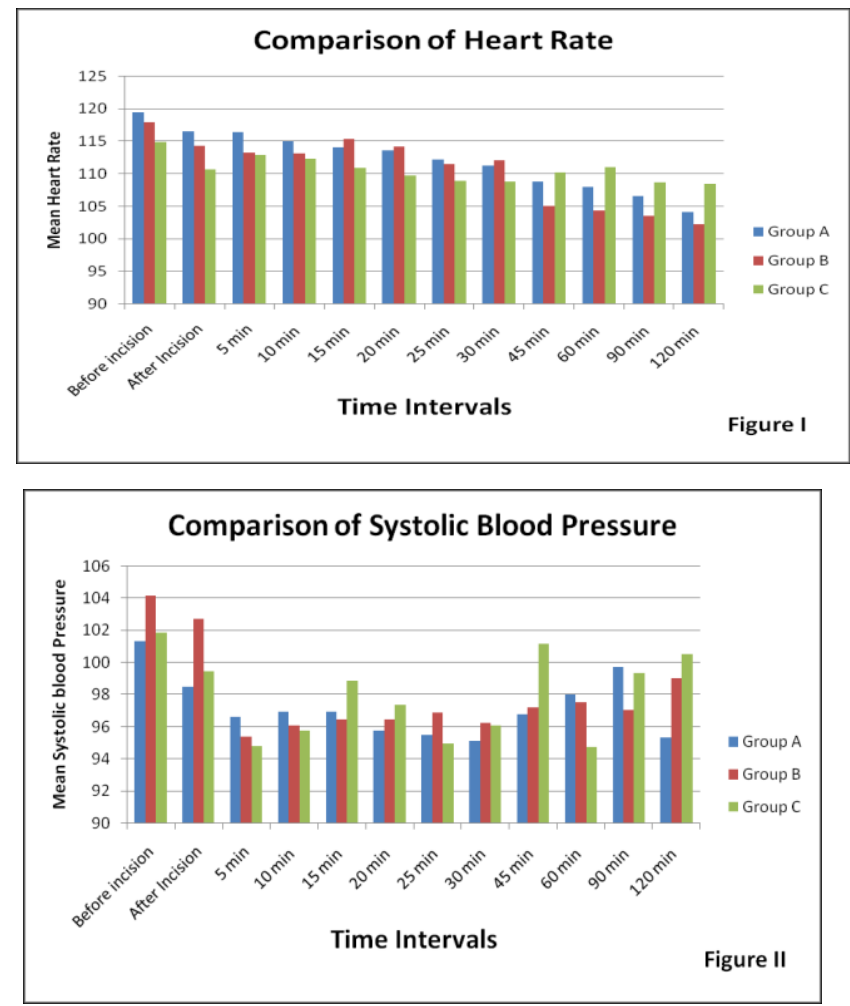

The two groups( Group A \& Group C )did not differ significantly on statistical analysis upto 4 hours of postoperative period with reference to total pain scores achieved at different postoperative intervals when assessed at 30 minutes, 1 hour, 2 hours and at 4 hours of postoperative period $(p>0.05)$. None of the patients in two groups had moderate or severe pain i.e. FLACC score $>4$ upto 4 hours. The two groups when compared with reference to total pain scores, the difference was found to be statistically significant $(\mathrm{p}<0.05)$. (TABLE 2$)$ 
Table - 2: Comparison of FLACC scores at various intervals in Postoperative period between Dexmedetomidine + Bupivacaine (Group A) and Bupivacaine (Group C)

\begin{tabular}{|c|c|c|c|c|c|c|c|}
\hline & \multicolumn{2}{|c|}{ Group A } & \multicolumn{2}{|c|}{ Group C } & \multirow{2}{*}{ p value } & \multirow{2}{*}{$\square^{2}$} \\
\hline & & $\mathbf{N}$ & $\%$ & $\mathbf{n}$ & $\%$ & & \\
\hline \multirow{3}{*}{$30 \mathrm{~min}$ FLACC } & No pain & 23 & 76.66 & 22 & 73.33 & \multirow{3}{*}{0.766} & \multirow{3}{*}{0.08} \\
\hline & Mild pain & 7 & 23.33 & 8 & 26.66 & & \\
\hline & Moderate pain & 0 & 0.00 & 0 & 0.00 & & \\
\hline \multirow{3}{*}{$\begin{array}{c}1 \text { hour } \\
\text { FLACC }\end{array}$} & No pain & 10 & 33.33 & 9 & 30.00 & \multirow{3}{*}{0.781} & \multirow{3}{*}{0.077} \\
\hline & Mild pain & 20 & 66.66 & 21 & 70.00 & & \\
\hline & Moderate pain & 0 & 0.00 & 0 & 0.00 & & \\
\hline \multirow{3}{*}{2 hour FLACC } & No pain & 9 & 30.00 & 6 & 20.00 & \multirow{3}{*}{0.37} & \multirow{3}{*}{0.8} \\
\hline & Mild pain & 21 & 70.00 & 24 & 80.00 & & \\
\hline & Moderate pain & 0 & 0.00 & 0 & 0.00 & & \\
\hline \multirow{3}{*}{4 hour FLACC } & No pain & 5 & 16.66 & 3 & 10.00 & \multirow{3}{*}{0.44} & \multirow{3}{*}{0.56} \\
\hline & Mild pain & 25 & 83.33 & 27 & 90.00 & & \\
\hline & Moderate pain & 0 & 0.00 & 0 & 0.00 & & \\
\hline \multirow{3}{*}{6 hour FLACC } & No pain & 4 & 13.33 & 3 & 10.00 & \multirow{3}{*}{0.02} & \multirow{3}{*}{7.10} \\
\hline & Mild pain & 19 & 63.33 & 10 & 33.33 & & \\
\hline & Moderate pain & 7 & 23.33 & 17 & 56.66 & & \\
\hline \multirow{3}{*}{10 hour FLACC } & No pain & 3 & 10.00 & 1 & 3.33 & \multirow{3}{*}{0.03} & \multirow{3}{*}{6.85} \\
\hline & Mild pain & 18 & 60.00 & 10 & 33.33 & & \\
\hline & Moderate pain & 9 & 30.00 & 19 & 63.33 & & \\
\hline \multirow{3}{*}{$\begin{array}{l}14 \text { hour } \\
\text { FLACC }\end{array}$} & No pain & 0 & 0.00 & 0 & 0.00 & \multirow{3}{*}{0.03} & \multirow{3}{*}{4.34} \\
\hline & Mild pain & 17 & 56.66 & 9 & 30.00 & & \\
\hline & Moderate pain & 13 & 43.33 & 21 & 70.00 & & \\
\hline \multirow{3}{*}{18 hour FLACC } & No pain & 0 & 0.00 & 0 & 0.00 & \multirow{3}{*}{0.03} & \multirow{3}{*}{4.44} \\
\hline & Mild pain & 16 & 53.33 & 8 & 26.66 & & \\
\hline & Moderate pain & 14 & 46.66 & 22 & 73.33 & & \\
\hline \multirow{3}{*}{24 hour FLACC } & No pain & 0 & 0.00 & 0 & 0.00 & \multirow{3}{*}{0.39} & \\
\hline & Mild pain & 20 & 66.66 & 23 & 76.66 & & 0.73 \\
\hline & Moderate pain & 10 & 33.33 & 7 & 23.33 & & \\
\hline
\end{tabular}

No pain $=$ FLACC 0; Mild pain $=$ FLACC 1-3; Moderate pain $=$ FLACC $4-7 ; n=$ Number of patients; $\%=$ Percentage

The FLACC score between groups B and C did not differ significantly on statistical analysis upto 4 hours of postoperative period with reference to total pain scores achieved at different postoperative intervals when assessed at 30 minutes, 1 hour, 2 hours and at 4 hours of postoperative period $(p>0.05)$. None of the patients in two groups had moderate or severe pain i.e. FLACC score $\geq 4$ upto 4 hours. The two groups when compared with reference to total pain scores, the difference was found to be statistically significant ( $p<$ 0.05).(TABLE3)

Table - 3: Comparison of FLACC scores at various intervals in Postoperative period Between Clonidine + Bupivacaine (Group B) and Bupivacaine alone (Group C)

\begin{tabular}{|c|c|c|c|c|c|c|c|}
\hline & & \multicolumn{2}{|c|}{ Group B } & \multicolumn{2}{|c|}{ Group C } & \multirow{2}{*}{ p value } & \multirow{2}{*}{$\square^{2}$} \\
\hline & & $\mathbf{N}$ & $\%$ & $\mathbf{n}$ & $\%$ & & \\
\hline \multirow{3}{*}{$\begin{array}{l}30 \mathrm{~min} \\
\text { FLACC }\end{array}$} & No pain & 23 & 76.66 & 22 & 73.33 & \multirow{3}{*}{0.76} & \multirow{3}{*}{0.08} \\
\hline & Mild pain & 7 & 23.33 & 8 & 26.66 & & \\
\hline & Moderate pain & 0 & 0.00 & 0 & 0.00 & & \\
\hline \multirow{3}{*}{$\begin{array}{l}1 \text { hour } \\
\text { FLACC }\end{array}$} & No pain & 8 & 26.66 & 9 & 30.00 & \multirow{3}{*}{0.77} & \multirow{3}{*}{0.08} \\
\hline & Mild pain & 22 & 73.33 & 21 & 70.00 & & \\
\hline & Moderate pain & 0 & 0.00 & 0 & 0.00 & & \\
\hline \multirow{3}{*}{$\begin{array}{l}2 \text { hour } \\
\text { FLACC }\end{array}$} & No pain & 7 & 23.33 & 6 & 20.00 & \multirow{3}{*}{0.75} & \multirow{3}{*}{0.08} \\
\hline & Mild pain & 23 & 76.66 & 24 & 80.00 & & \\
\hline & Moderate pain & 0 & 0.00 & 0 & 0.00 & & \\
\hline \multirow{3}{*}{$\begin{array}{c}4 \text { hour } \\
\text { FLACC }\end{array}$} & No pain & 7 & 23.33 & 3 & 10.00 & \multirow{3}{*}{0.16} & \multirow{3}{*}{0.18} \\
\hline & Mild pain & 23 & 76.66 & 27 & 90.00 & & \\
\hline & Moderate pain & 0 & 0.00 & 0 & 0.00 & & \\
\hline
\end{tabular}




\begin{tabular}{|c|c|c|c|c|c|c|c|}
\hline \multirow{3}{*}{$\begin{array}{l}6 \text { hour } \\
\text { FLACC }\end{array}$} & No pain & 2 & 6.66 & 3 & 10.00 & \multirow{3}{*}{0.02} & \multirow{3}{*}{7.10} \\
\hline & Mild pain & 21 & 70.00 & 10 & 33.33 & & \\
\hline & Moderate pain & 7 & 23.33 & 17 & 56.66 & & \\
\hline \multirow{3}{*}{$\begin{array}{l}10 \text { hour } \\
\text { FLACC }\end{array}$} & No pain & 2 & 6.66 & 1 & 3.00 & \multirow{3}{*}{0.05} & \multirow{3}{*}{5.3} \\
\hline & Mild pain & 18 & 60.00 & 10 & 33.33 & & \\
\hline & Moderate pain & 10 & 33.33 & 19 & 63.33 & & \\
\hline \multirow{3}{*}{$\begin{array}{l}14 \text { hour } \\
\text { FLACC }\end{array}$} & No pain & 0 & 0.00 & 0 & 0.00 & \multirow{3}{*}{0.049} & \multirow{3}{*}{3.26} \\
\hline & Mild pain & 16 & 53.33 & 9 & 30.00 & & \\
\hline & Moderate pain & 14 & 46.66 & 21 & 70.00 & & \\
\hline \multirow{3}{*}{$\begin{array}{l}18 \text { hour } \\
\text { FLACC }\end{array}$} & No pain & 0 & 0.00 & 0 & 0.00 & \multirow{3}{*}{0.49} & \multirow{3}{*}{3.26} \\
\hline & Mild pain & 15 & 50.00 & 8 & 26.66 & & \\
\hline & Moderate pain & 15 & 50.00 & 22 & 73.33 & & \\
\hline \multirow{3}{*}{$\begin{array}{l}24 \text { hour } \\
\text { FLACC }\end{array}$} & No pain & 0 & 0.00 & 0 & 0.00 & \multirow{3}{*}{0.55} & \multirow{3}{*}{0.34} \\
\hline & Mild pain & 21 & 70.00 & 23 & 76.66 & & \\
\hline & Moderate pain & 9 & 30.00 & 7 & 23.33 & & \\
\hline
\end{tabular}

$=$ Percentage

No pain $=$ FLACC $0 ;$ Mild pain $=$ FLACC 1-3; Moderate pain $=$ FLACC 4-7; $n=$ Number of patients; $\%$

The two groups( Group A \& Group B) were compared with reference to total pain scores at various intervals postoperatively i.e. at 30 minutes, 1 hour, 2 hours, 4 hours, 6 hours, 10 hours, 14 hours, 18 hours and at 24 hours as depicted in the table (TABLE 4). The difference between the two groups at all these intervals was found to be statistically insignificant ( $\mathrm{p}>0.05)$, showing that the two groups were having similar quality of pain relief when compared at various intervals in the postoperative period.

Table - 4: Comparison of FLACC scores at various intervals in Postoperative period Between Dexmedetomidine + Bupivacaine (Group A) and Clonidine + Bupivacaine (Group B)

\begin{tabular}{|c|c|c|c|c|c|c|c|}
\hline & & \multicolumn{2}{|c|}{ Group A } & \multicolumn{2}{|c|}{ Group B } & \multirow{2}{*}{ p value } & \multirow{2}{*}{$\square^{2}$} \\
\hline & & $\mathbf{N}$ & $\%$ & n & $\%$ & & \\
\hline \multirow{3}{*}{$\begin{array}{c}30 \mathrm{~min} \\
\text { FLACC }\end{array}$} & No pain & 23 & 76.66 & 23 & 76.66 & \multirow{3}{*}{1.00} & \multirow{3}{*}{$\begin{array}{c}0.0 \\
0\end{array}$} \\
\hline & Mild pain & 7 & 23.33 & 7 & 23.33 & & \\
\hline & Moderate pain & 0 & 0.00 & 0 & 0.00 & & \\
\hline \multirow{3}{*}{$\begin{array}{c}1 \text { hour } \\
\text { FLACC }\end{array}$} & No pain & 10 & 33.33 & 8 & 26.66 & \multirow{3}{*}{0.57} & \multirow{3}{*}{$\begin{array}{c}0.3 \\
1\end{array}$} \\
\hline & Mild pain & 20 & 66.66 & 22 & 73.33 & & \\
\hline & Moderate pain & 0 & 0.00 & 0 & 0 & & \\
\hline \multirow{3}{*}{$\begin{array}{c}2 \text { hour } \\
\text { FLACC }\end{array}$} & No pain & 9 & 30.00 & 7 & 23.33 & \multirow{3}{*}{0.55} & \multirow{3}{*}{$\begin{array}{c}0.3 \\
0\end{array}$} \\
\hline & Mild pain & 21 & 70.00 & 23 & 76.66 & & \\
\hline & Moderate pain & 0 & 0.00 & 0 & 0.00 & & \\
\hline \multirow{3}{*}{$\begin{array}{c}4 \text { hour } \\
\text { FLACC }\end{array}$} & No pain & 5 & 16.66 & 7 & 23.33 & \multirow{3}{*}{0.51} & \multirow{3}{*}{$\begin{array}{c}0.4 \\
0\end{array}$} \\
\hline & Mild pain & 25 & 83.33 & 23 & 76.66 & & \\
\hline & Moderate pain & 0 & 0.00 & 0 & 0.00 & & \\
\hline \multirow{3}{*}{$\begin{array}{c}6 \text { hour } \\
\text { FLACC }\end{array}$} & No pain & 4 & 13.33 & 2 & 6.66 & \multirow{3}{*}{0.68} & \multirow{3}{*}{$\begin{array}{c}0.7 \\
6\end{array}$} \\
\hline & Mild pain & 19 & 63.33 & 21 & 70.00 & & \\
\hline & Moderate pain & 7 & 23.33 & 7 & 23.33 & & \\
\hline \multirow{3}{*}{$\begin{array}{l}10 \text { hour } \\
\text { FLACC }\end{array}$} & No pain & 3 & 10.00 & 2 & 6.66 & \multirow{3}{*}{0.88} & \multirow{3}{*}{$\begin{array}{c}0.2 \\
5\end{array}$} \\
\hline & Mild pain & 18 & 60.00 & 18 & 60.00 & & \\
\hline & Moderate pain & 9 & 30.00 & 10 & 33.33 & & \\
\hline \multirow{3}{*}{$\begin{array}{l}14 \text { hour } \\
\text { FLACC }\end{array}$} & No pain & 0 & 0.00 & 0 & 0.00 & \multirow{3}{*}{0.79} & \multirow{3}{*}{$\begin{array}{c}0.0 \\
6\end{array}$} \\
\hline & Mild pain & 17 & 56.66 & 16 & 53.33 & & \\
\hline & Moderate pain & 13 & 43.33 & 14 & 46.66 & & \\
\hline \multirow{3}{*}{$\begin{array}{l}18 \text { hour } \\
\text { FLACC }\end{array}$} & No pain & 0 & 0.00 & 0 & 0.00 & \multirow{3}{*}{0.79} & \multirow{3}{*}{$\begin{array}{c}0.0 \\
6\end{array}$} \\
\hline & Mild pain & 16 & 53.33 & 15 & 50.00 & & \\
\hline & Moderate pain & 14 & 46.66 & 15 & 50.00 & & \\
\hline \multirow{3}{*}{$\begin{array}{l}24 \text { hour } \\
\text { FLACC }\end{array}$} & No pain & 0 & 0.00 & 0 & 0.00 & \multirow{3}{*}{0.78} & \multirow{3}{*}{$\begin{array}{c}0.0 \\
7\end{array}$} \\
\hline & Mild pain & 20 & 66.66 & 21 & 70.00 & & \\
\hline & Moderate pain & 10 & 33.33 & 9 & 30.00 & & \\
\hline
\end{tabular}

No pain $=$ FLACC 0; Mild pain $=$ FLACC 1-3; Moderate pain $=$ FLACC 4-7; $n=$ Number of patients; $\%=$ Percentage

When groups $\mathrm{A}$ and $\mathrm{C}$ were compared, the difference in the mean duration of postoperative analgesia between the two groups was found to be statistically significant $(\mathrm{p}<0.05)$. Similarly, when the groups B and $\mathrm{C}$ were compared, the difference between the mean duration of postoperative analgesia was found to be statistically significant between the two groups $(p<0.05)$. However, the difference in the mean duration of postoperative analgesia was found to be statistically insignificant when group A was compared to group B (p > 0.05). (TABLE 5) 
Table - 5: Comparison of Mean Duration of Postoperative Analgesia between the Three Studied Groups

\begin{tabular}{|c|c|c|c|}
\hline Group & Mean & Minimum & Maximum \\
\hline A & $14.43 \pm 2.58$ & 10.00 & 18.00 \\
\hline B & $13.53 \pm 2.01$ & 10.00 & 18.00 \\
\hline C & $6.06 \pm 1.85$ & 4.00 & 10.00 \\
\hline \multicolumn{3}{|c|}{ A vs. C } & 0.0001 \\
\hline \multirow{2}{*}{ P - value: } & B vs. C & 0.0001 \\
\hline
\end{tabular}

Group A = Dexmedetomidine + Bupivacaine; Group B = Clonidine + Bupivacaine;

Group $\mathrm{C}=$ Bupivacaine alone

The three groups were compared for postoperative complications and the difference between the groups was found to be statistically insignificant $(\mathrm{p}>0.05)$. (Figure III)

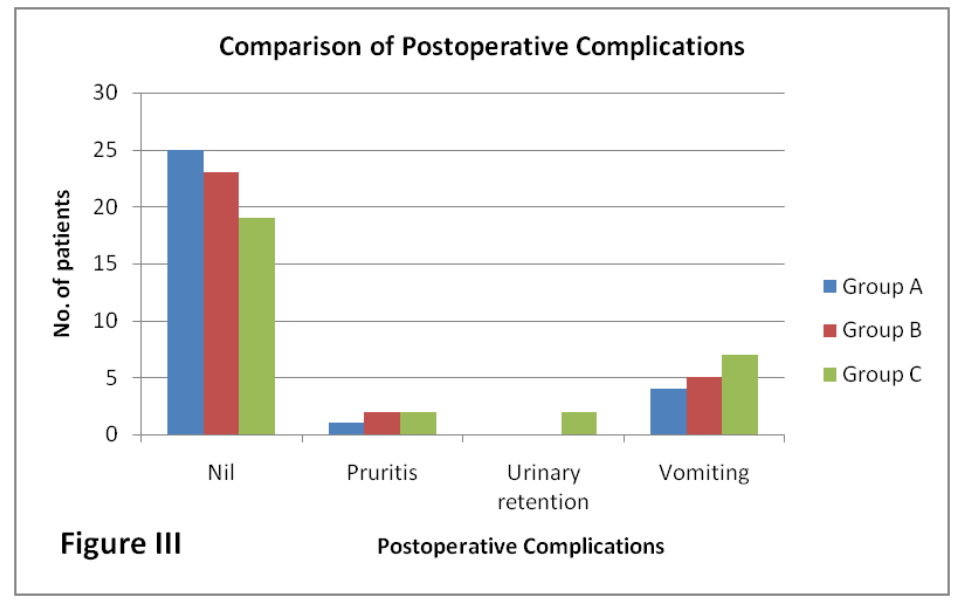

\section{Discussion}

Caudal block is one of the most common regional anaesthetic technique used in children. It is considered safe and simple procedure but its main disadvantage is its relatively short duration of action even with use of long acting agents such as bupivacaine ${ }^{[8]}$. The successful use of epidural clonidine in adults leads to its evaluation in paediatric caudal block. The resulting studies have consistently shown caudal clonidine to increase the duration of postoperative analgesia. ${ }^{[9,10]}$ On the other hand dexmedetomidine compared to clonidine is much more selective alpha-2 adrenoreceptor agonist which might permit its application in relatively high doses for sedation and analgesia without unwanted vascular effects from activation of alpha-1 receptors. ${ }^{[11]}$

All the three groups were homogenous with reference to age, sex, body weight and duration of surgery and anaesthesia. Mean age of patients was $5.0+2.14$ years in group A, 4.3 \pm 2.6 years in group B and $3.7 \pm 2.5$ years in group $\mathrm{C}$ respectively. Mean weight of patients was $17.7 \pm 3.9 \mathrm{kgs}$ in group $\mathrm{A}, 17.7 \pm 5.6 \mathrm{kgs}$ in group $\mathrm{B}$ and $15.1 \pm 6.5 \mathrm{kgs}$ in group $\mathrm{C}$ respectively.

Heart rate, systolic blood pressure and oxygen saturation $\left(\mathrm{SpO}_{2} \%\right)$ by pulse oximetry were recorded at various intervals in perioperative period starting from baseline values upto the time when the patients were discharged from recovery room. The groups when compared with reference to mean heart rate and mean systolic blood pressure at various intervals perioperatively, the difference was found to be statistically insignificant ( $p$ value $>0.05$ ). None of the patients in any group developed bradycardia (heart rate $<60 / \mathrm{min}$ ) or hypotension (systolic arterial pressure $<70+$ twice the age in years associated with altered peripheral perfusion). No significant respiratory depression was reported in any patient in this study and none of the patients had a $\mathrm{SpO}_{2}$ value of $<95 \%$ on pulse oximetry).

Our observations correlate with Klimsha et al ${ }^{[12]}$ who found no significant hemodynamic effects in their patients receiving either 1 or $2 \mu \mathrm{g} / \mathrm{kg}$ of caudal clonidine. A.M. El-Hennawy et al [ ${ }^{13]}$ also found no significant difference in the magnitude of hemodynamic changes in perioperative period when either dexmedetomidine $2 \square \mathrm{g} / \mathrm{kg}$ or clonidine $2 \square \square \mathrm{g} / \mathrm{kg}$ was added to caudal bupivacaine $0.25 \%$ in paediatric patients undergoing subumblical surgeries.

Quality of postoperative analgesia was assessed by using FLACC pain scale scoring at 30 minutes interval upto 1 hour in the recovery room, thereafter at 2 hours, 4 hours, 6 hours and subsequently every 4 hourly upto 18 hours and then at 24 hours of postoperative period. 
We found from our observation that upto 4 hours of postoperative period all the patients in our study had adequate caudal analgesia (FLACC score $<4$ ). Subsequently the number of patients with adequate caudal analgesia declined in all the three groups but the decline was more rapid in group $\mathrm{C}$ as compared to group $\mathrm{A}$ or B. Group C patients achieved significantly higher FLACC scores compared to groups A and B.

Our results are in correlation with the study conducted the A.M. El-Hennawy ${ }^{[13]}$ who in their study observed better quality of analgesia in groups receiving either dexmedetomidine or clonidine combined with bupivacaine compared to groups receiving $0.25 \%$ bupivacaine alone.

Duration of postoperative analgesia (time of maintaining adequate caudal analgesia FLACC $<4$ ) was $14.4 \pm 2.5$ hour in group $\mathrm{A}, 13.5 \pm 2.6$ hour in group $\mathrm{B}$ and $4.6 \pm 1.8$ hour in group $\mathrm{C}$. When group $\mathrm{C}$ was compared to group $\mathrm{A}$ or group $\mathrm{B}$ with reference to postoperative analgesia time it was found that the mean duration of postoperative analgesia was shorter in group $\mathrm{C}$ as compared to group $\mathrm{A}$ or group $\mathrm{B}$ and the difference was found to be statistically significant $(\mathrm{p}<0.05)$. However the difference between group A and B was found to be statistically insignificant $(\mathrm{p}>0.05)$.

Our results are similar to the study of I. Saadawy et al ${ }^{[14]}$ who reported longer duration of postoperative analgesia and better quality of sleep after administration of caudal dexmedetomidine $(2 \square \mathrm{g} / \mathrm{kg})$ plus bupivacaine $(0.25 \%)$ as compared when bupivacaine $(0.25 \%)$ was given alone. This was confirmed by longer interval to first request of rescue analgesics and significantly lowers consumption of rescue analgesics in postoperative period.

In our study we observed that during 24 hour of postoperative period 21 patients in group $\mathrm{C}$ received rescue analgesic doses as compared to 8 patients in group A and 10 patients in group B. It was observed that analgesic requirement in group $\mathrm{C}$ was significantly higher as compared to groups $\mathrm{A}$ and $\mathrm{B}$ and the difference was found to be statistically significant $(p<0.05)$. However the difference in the requirement of rescue analgesics was insignificant between groups $\mathrm{A}$ and $\mathrm{B}$.

Our results are in correlation with the study of A.M. El-Hennawy ${ }^{[13]}$ who observed less use of analgesics in postoperative period in groups receiving either caudal dexmedetomidine or clonidine combined with bupivacaine in comparison with the group receiving bupivacaine alone.

The incidence of postoperative complications like nausea, vomiting, and urinary retention was comparable between the groups in our study $(\mathrm{p}>0.05)$. Aruna Parameswari et al ${ }^{[15]}$ also observed that no significant increase in incidence of pruritis, urinary retention after administration of caudal clonidine with bupivacaine $0.25 \%$.

In conclusion we found that the addition of both dexmedetomidine and clonidine offered better quality of postoperative analgesia as compared to bupivacaine alone. Moreover dexmedetomidine did not offer significant advantage over clonidine as regards the duration of postoperative analgesia.

\section{References}

[1] Choonara IA: Management of pain in newborn infants. Semi Perinatol 1992; 16:32-40

[2] Campbell MF: Caudal anesthesia in children. Am J Urol 1933; 30:245-9

[3] Ansermino M, Basu R, and Vandebeek C, et al. Nonopioid additives to local anesthetics for caudal blockade in children: a systemic revive. Paediatr. Anaesth 2003; 13:501-73.

[4] Kumar P, Rudra A, Pan AK, Achariya A. caudal additives in pediatrics. A comparison among midazolam, Ketamine and Neostigmine co-administered with bupivacaine. Anesth-Analgesia 2005; 10: 69-73.

[5] Sheinin M, Pihlavisto M. Molecular pharmacology of alpha 2 adrenoreceptor agonists. Bailliere's Clin Anaesth 2000; 14: 247-60.

[6] Coursin DB, Maccioli GA. Dexmedetomidine. Curr Opin Crit Care 2001; 7: 221-42.

[7] Housmans PR. Effects of dexmedetomidine on contractility, relaxation and intracellular calcium transients of isolated ventricular myocardium. Anaesthesiology 1990; 73: 919-922.

[8] Rowney DA, Doyle E. Epidural and subarachnoid blockade in children. Anaesthesia 1998; 58:980-1001.

[9] De Mey JC, Strobbet I, Poelaert, et al. The influence of sulfentanil and/or clonidine on the duration of analgesia after caudal block for hypospadias repair surgery in children. Eur J Anaesthesiol 2000; 17: 379-82.

[10] De Beer DAH, Thomas M. Caudal additives in children-Solution or problems? Br J Anaesth 2003; 90(4): 487-98.

[11] Calzada B.C., De Artinano A.A. Alpha-2-adrenoreceptor subtypes. Pharmacol Res. 2001; 44: 195-208.

[12] Klimsha W, Chiari A, Michalek-Sauberer A, et al: The efficiency and safety of Clonidine-Bupivacaine combination in caudal blockade for pediatric hernia repair. Anesthesia Analgesia 1998; 6: 54-61.

[13] A.M. El-Hennawy, A.M. Abd-Elwahab, A.M. Abd Elmaksoud, et al. Addition of clonidine or dexmedetomidine to bupivacaine prolongs caudal analgesia in children. Br J Anaesth 2009; 103(2): 268-274.

[14] I. Saadawy, A Boker, M. A. ElshahawyL, W. Afifi et al. Effects of dexmedetomidine on the characteristics of the bupivacaine in a caudal block in pediatrics. Acta Anaesthesiologica Scand Feb. 2009; Vol. 53(2): 35

[15] Aruna Parameswari, Anand M Dhev, Mahesh Vakamudi, et al. Efficacy of clonidine as an adjuvant to bupivacaine for caudal analgesia in children undergoing sub-umbilical surgery. Indian Journal of Anaesthesia 2010; 54(5): 458-63. 